\title{
Inulin addition on flavored homemade bread: physico- chemical composition and sensory acceptance among schoolchildren
}

\section{Adição de inulina em pão caseiro saborizado: composição físico-química e aceitação sensorial entre escolares}

\author{
Jaqueline Hack' \\ Michele Dal Santos ${ }^{2}$ \\ Elisvânia Freitas dos Santos ${ }^{3}$ \\ Fabiane La Flor Ziegler Sanches ${ }^{4}$ \\ Maria Raquel Manhani ${ }^{5}$ \\ Daiana Novello6(*)
}

\section{Abstract}

The study assessed the sensory acceptability of homemade bread flavored with pineapple rind tea added with inulin well as tried to determine the physico-chemical composition of the traditional formulation and also verified the formulation that contains the highest inulin level and sensory acceptance similar to the standard. It was used the following five bread formulations: standard (F1) and others added $20 \%(\mathrm{~F} 2), 25 \%(\mathrm{~F} 3), 30 \%(\mathrm{~F} 4)$ and 35\% (F5) inulin. The participants of the sensory analysis were 50 untrained tasters, from both genders, between 7 and 10 years. In the physico-chemical analysis, it was determined the moisture content, ash, protein, fat, carbohydrates, crude fiber and calories. Sensorially, the sample F5 had lower grades than others in the appearance tribute and lower grades than the standard sample for the flavor attribute $(\mathrm{p}<0.05)$. Therefore, the sample with $30 \%$ inulin

I Nutricionista; Departamento de Nutrição, Universidade Estadual do Centro-Oeste, UNICENTRO; Endereço: Rua Simeão Camargo Varela de Sá, 3, CEP: 85040-080, Guarapuava, Paraná, Brasil; E-mail: jaq_ hack@hotmail.com

2 Nutricionista; Departamento de Nutrição, Universidade Estadual do Centro-Oeste, UNICENTRO; Endereço: Rua Simeão Camargo Varela de Sá, 3, CEP: 85040-080, Guarapuava, Paraná, Brasil; E-mail: micheledalsantos@hotmail.com

3 Dra.; Nutricionista; Professora Adjunta do Departamento de Nutrição, Universidade Federal de Mato Grosso do Sul, UFMS; Endereço: Cidade Universitária, s/no, Caixa-Postal: 549, CEP: 79070900 - Campo Grande, Mato Grosso do Sul - Brasil; E-mail: elisvania@gmail.com

4 Dra.; Nutricionista; Professora adjunta do Departamento de Nutrição, Universidade Federal de Mato Grosso do Sul, UFMS; Endereço: Cidade Universitária, s/no, Caixa-Postal: 549, Campo Grande, Mato Grosso do Sul - Brasil; E-mail: fabianelaflor@gmail.com

5 Dra.; Química Tecnológica; Professora Adjunta do Departamento de Farmácia e Nutrição, Universidade São Judas Tadeu, São Paulo; Endereço: Rua Taquari, 546, Mooca, CEP: 03 I66-000, São Paulo, São Paulo Brasil; E-mail: rmanhani@yahoo.com.br

6 Dra.; Tecnologia de alimentos; Professora do Departamento de Nutrição da Universidade Estadual do Centro-Oeste, UNICENTRO; Endereço: Rua Simeão Camargo Varela de Sá, 03, CEP: 85040-080, Guarapuava, Paraná, Brasil; E-mail: nutridai@gmail.com (*) Autora para correspondência 
was regarded as the product with a higher content of the ingredient and with sensory acceptance like the standard. In the physico-chemical composition, the sample with 30\% inulin showed lower content of moisture, proteins and calories and higher contents of carbohydrates and crude fiber than the standard. Thus, the development of the products proved that an addition level up to $30 \%$ inulin in sliced loaves was better accepted, obtaining a sensory acceptance similar to the standard product, showing good marketing expectations.

Key words: cereal; prebiotics; fibers.

\section{Resumo}

Objetivou-se verificar a aceitabilidade sensorial de pão caseiro saborizado com chá da casca de abacaxi com adição de inulina, bem como determinar a composição físico-química da formulação tradicional e daquela contendo maior nível de inulina e com aceitação sensorial semelhante a padrão. Utilizaram-se cinco formulações de pães sendo: padrão (F1) e as demais adicionadas de 20\% (F2), 25\% (F3), 30\% (F4) e $35 \%$ (F5) de inulina. Participaram da análise sensorial 50 provadores não treinados, de ambos os gêneros, com idade entre 7 e 10 anos. Nas análises físico-químicas foram determinados o teor de umidade, cinzas, proteínas, lipídios, carboidratos, fibra bruta e valor calórico. Sensorialmente, a amostra F5 apresentou menores notas que as demais no atributo aparência e menor nota que a amostra padrão para o atributo sabor $(\mathrm{p}<0,05)$. Portanto, a amostra com $30 \%$ de inulina foi considerada como o produto com maior teor do ingrediente e aceitação sensorial semelhante a padrão. $\mathrm{Na}$ composição físico-química, a amostra com $30 \%$ de inulina apresentou menores teores de umidade, proteínas e calorias e maiores de carboidratos e fibra bruta $(\mathrm{p}<0,05)$ que a padrão. Sendo assim, a elaboração dos produtos permitiu comprovar que um nível de adição de até 30\% de inulina em pão de forma foi melhor aceito, obtendo-se aceitação sensorial semelhante ao produto padrão e com boas expectativas de comercialização.

Palavras-chave: cereais; prebióticos; fibras.

\section{Introduction}

The production of new beneficial foods to health presents growing scientific and commercial support. Among these there are products with low calorie and fiber enriched using ingredients such as fructooligosaccharides (FOS) and inulin. These products present many advantages, because they can replace, mainly, sugar and fat in food products (FRANCK, 2002; ISIK et al., 2011; MANTZOURIDOU et al., 2012).

Inulin is a storage of polysaccharide presented in several plants such as onion, garlic, wheat, leeks, banana and chicory. Its industrial extraction occurs mainly from the latter (FRANCK, 2002; MEYER et al., 2011). It can be considered a soluble fiber and prebiotic because it is not digested by 
the gastrointestinal tract and it is used as a substrate for beneficial colonic bacteria, contributing to the improvement of the intestinal microflora (MANTZOURIDOU et al., 2012).

The wide use of inulin in food industry is based on their nutritional and technological properties (MUZZARELLI et al., 2011). It is used in various products such as confectionery, beverages, dairy products, cereal bars, ice cream and others (MEYER et al., 2007; ISIK et al., 2011; GRANATO et al., 2012). Bread is a great tool for adding functional ingredients such as inulin, because in addition to supply a meaningful portion of daily energy and nutrients, it is highly consumed by the population (VASCONCELOS et al., 2006).

Thus, the food technology is being applied to products through enrichment techniques, by adding functional properties, lower costs, among others, searching for some kind of contribution for the food industry as well as aiming at bringing health benefits to people (MORRIS; MORRIS, 2012). However, to make a new product it is fundamental its assessment through sensory analysis in order to study its development, optimization and consumer acceptance (VON ATZINGEN; PINTO E SILVA, 2010). It is noteworthy that the sensory characteristics of added ingredients in products should look like the standard product and also reduce the substitution effects to obtain food with good appearance, aroma, taste, color and texture (MINIM, 2010; DUTCOSKI, 2011).

It is known that childhood is the development stage of eating habits, which turns the school into an environment conducive to encourage the consumption of nutritionally adequate food. Thus, it becomes important to introduce healthy food in age from 7 to 10 years, considered school age, and analyze the physico-chemical composition of the standard product because once the child acquires the right eating habits, they will hardly be modified in adulthood (VON ATZINGEN; PINTO E SILVA, 2010).

Thus, the goal of this study was to prepare flavored homemade bread added with inulin to evaluate the sensory acceptability among school-age children and to analyze the physico-chemical composition of the standard product and also to determine the ones with higher inulin content and similar acceptance.

\section{Material and Methods}

\section{Raw material acquisition}

The products were purchased in supermarkets in Guarapuava, PR and inulin was donated by national partner companies.

\section{Pineapple peel tea acquisition}

First, pineapple was cleaned with running water and left in a sodium hypochlorite solution (chlorine concentration of 2 to $2.5 \%$ ) for 15 minutes and then peeled. For the tea preparation, $300 \mathrm{~g}$ of pineapple rinds were boiled in $500 \mathrm{ml}$ of water $\left(100^{\circ} \mathrm{C}\right)$ for 5 minutes and the liquid drained and the rinds discarded.

\section{Formulations}

Five formulations of homemade bread were added to the pineapple rind tea and inulin. For the purposes of classification it was considered only the inulin addition, as follows: F1 standard (0\%), F2 (20\%), 
F3 (25\%), F4 (30\%) and F5 (35\%). These percentages were defined after sensory preliminary with the product. In Chart 1 it can be verified bread formulations added with inulin.

The formulations were prepared individually in Technical Dietetics Laboratory of the Nutrition Department at the Midwest State University - UNICENTRO. The weight of all the ingredients was performed on a digital scale (Filizola ${ }^{\circledR}$, Brasil) with a precision of $0.1 \mathrm{~g}$ and a maximum capacity of $15 \mathrm{~kg}$. First, all ingredients were manually mixed, kneaded and left to rest for fermentation for 30 minutes. Inulin was added in the amount presented in Chart 1. The resulting dough was delivered in aluminum molds $30 \times 12 \mathrm{~cm}$ and baked in a preheated oven $\left(\right.$ Brastemp $^{\circledR}$, Brasil) at $200^{\circ} \mathrm{C}$ for 50 minutes

\section{Sensory analysis}

The participants of this research were 50 untrained children, enrolled in a Municipal School in Guarapuava, Paraná, of both genders, aged between 7 and 10 years.

The products were subjected to a sensory evaluation, in a specific school room, with each student being evaluated at a time. Each test was performed in individual booths, type urn, and the children were assisted by the researchers to fill the answers the questionnaires.

The sensorial trial evaluated the sensory attributes of appearance, aroma, taste, texture and color through a structured hedonic facial scale of 7 points ranging from 1 (“Super Bad") to 7 (“Super Good”), adapted from Kimmel et al. (1994). It was also applied global questions of acceptance and purchase intention through a structured hedonic scale of 5 points ( 1 "disliked very much"/"would not buy" to 5 "really liked" /"would buy definitely"), as suggested by Minim (2010).

Each judge received a portion of each sample (approximately $10 \mathrm{~g}$ ) in disposable white plastic dishes, coded with three digit numbers, in a randomized, balanced, followed by a glass of water for conducting the samples. The formulations were offered to judges in a sequential monadic way.

\section{Acceptability index (AI)}

The index calculation of acceptability of five formulations was performed according to Monteiro (1984), based on the formula:

Chart 1 - Formulations ingredients of flavored homemade bread added of tea from pineapple peel and inulin

\begin{tabular}{lccccc}
\hline Ingredients & F1 & F2 & F3 & F4 & F5 \\
\hline Refined wheat flour (\%) & 52,63 & 44,21 & 39,21 & 34,21 & 29,21 \\
Pineapple peel tea (\%) & 21,05 & 21,05 & 21,05 & 21,05 & 21,05 \\
Crystal sugar (\%) & 11,58 & 0,00 & 0,00 & 0,00 & 0,00 \\
Egg yolk (\%) & 6,32 & 6,32 & 6,32 & 6,32 & 6,32 \\
Margarine (\%) & 5,26 & 5,26 & 5,26 & 5,26 & 5,26 \\
Fresh yeast (\%) & 3,16 & 3,16 & 3,16 & 3,16 & 3,16 \\
Inulin powder (\%) & 0,00 & 20,00 & 25,00 & 30,00 & 35,00 \\
\hline
\end{tabular}

Source:Authors (20/3).

Note: FI: standard; F2: $20 \%$ of inulin; F3: $25 \%$ of inulin; F4: $30 \%$ of inulin; F5: $35 \%$ of inulin. 
AI $(\%)=100 \times \mathrm{A} / \mathrm{B}$ (A: average score obtained for the product, $\mathrm{B}$ : maximum score given to the product).

\section{Physico-chemical analyzes}

The physico-chemical analyzes were performed at the Food Analysis Laboratory in the Food Engineering Department at UNICENTRO and in the Food Science and Food Composition Laboratory at São Judas Tadeu University, in São Paulo, SP.

The following physico-chemical determinations were performed in triplicate in the standard bread (F1) and in the formulation with higher inulin content, which obtained a similar sensory acceptance to the standard one:

Moisture: it was determined at $105^{\circ} \mathrm{C}$ in a greenhouse up the constant weight, according to AOAC (2011); Ash: it was analyzed in oven $\left(550^{\circ} \mathrm{C}\right)$, according to AOAC (2011); Total Lipids: it was used the cold extraction method (BLIGH; DYER, 1959); Protein: it was evaluated by total nitrogen content from the sample by the Kjeldahl method, established semimicro level (AOAC, 2011). We used the nitrogen conversion factor of 6.25 for protein; Crude Fiber: it was used the hot extraction method $\mathrm{H}_{2} \mathrm{SO}_{4}(1.25 \% \mathrm{w} / \mathrm{v})$ and $\mathrm{NaOH}(1.25 \%$ w/v) AOAC (2011) Carbohydrate: The carbohydrates determination (including crude fiber) of the products were performed by theoretical calculation (by difference) in the triplicate results, according to the formula: $\%$ Carbohydrates $=100-(\%$ moisture $+\%$ protein $+\%$ fat $+\%$ ash); Calories: Total calories (kcal) were calculated for $50 \mathrm{~g}$ of sample, using the next numbers: lipids $(8.37 \mathrm{kcal} / \mathrm{g})$, proteins $(3.87 \mathrm{kcal} / \mathrm{g})$, and carbohydrates $(4.11 \mathrm{kcal} / \mathrm{g})$ (MERRILL; WATT, 1973), and to inulin:1,5 kcal/g (carbohydrates) $\left(\right.$ BENEO $\left.^{\circledR} \mathrm{HP}, 2012\right)$.

\section{Determination of the Reference Daily Value (DV)}

For the calculation of DV, it was performed an average of the recommended values by Dietary Reference Intakes (2005), for children (7-10 years). The nutrients were assessed by the average calculations: 1802.55 $\mathrm{kcal} /$ day, $258.89 \mathrm{~g}$ carbohydrates, $62.92 \mathrm{~g}$ protein and $65.91 \mathrm{~g}$ lipid.

\section{Ethical issues}

This study was approved by the Ethics Committee of Research at UNICENTRO, opinion number no. 49549/2012. However, as exclusion criteria for the participants it was considered the following factors: having allergy to any ingredient used in the bread preparations, not belonging to the same school proposed by the research and not delivering the Informed Consent Form Document (ICFD), signed by the legal guardian.

\section{Statistical analysis}

Data were analyzed using the Statgraphics Plus ${ }^{\circledR}$ software version 5.1, through variance analysis (ANOVA), by knowing that average comparison was performed by the Tukey average test and $t$ of student, both with $5 \%$ significance level.

\section{Results and Discussion}

\section{Sensorial analysis}

Chart 2 presents sensory acceptance in flavored bread standard and added with inulin. 
Chart 2 - Averages from sensory test and purchase intent performed for flavored pineapple bread formulations standard and enriched with 20, 25, 30 and 35\% inulin

\begin{tabular}{lccccc}
\hline $\begin{array}{l}\text { Formulations/ } \\
\text { Attributes }\end{array}$ & $\begin{array}{c}\text { F1 } \\
\text { Mean } \pm \text { SD }\end{array}$ & $\begin{array}{c}\text { F2 } \\
\text { Mean } \pm S D\end{array}$ & $\begin{array}{c}\text { F3 } \\
\text { Mean } \pm S D\end{array}$ & $\begin{array}{c}\text { F4 } \\
\text { Mean } \pm S D\end{array}$ & $\begin{array}{c}\text { F5 } \\
\text { Mean } \pm S D\end{array}$ \\
\hline Appearance & $6,33 \pm 1,03^{\mathrm{a}}$ & $6,23 \pm 0,91^{\mathrm{a}}$ & $6,27 \pm 0,89^{\mathrm{a}}$ & $6,20 \pm 0,87^{\mathrm{a}}$ & $5,64 \pm 1,28^{\mathrm{b}}$ \\
Aroma & $6,32 \pm 1,07^{\mathrm{a}}$ & $6,18 \pm 1,02^{\mathrm{a}}$ & $6,01 \pm 1,11^{\mathrm{a}}$ & $6,11 \pm 1,23^{\mathrm{a}}$ & $6,20 \pm 1,09^{\mathrm{a}}$ \\
Taste & $6,58 \pm 0,77^{\mathrm{a}}$ & $6,29 \pm 0,83^{\mathrm{ab}}$ & $6,29 \pm 0,99^{\mathrm{ab}}$ & $6,17 \pm 1,04^{\mathrm{ab}}$ & $6,00 \pm 1,36^{\mathrm{b}}$ \\
Texture & $6,29 \pm 0,94^{\mathrm{a}}$ & $6,14 \pm 1,05^{\mathrm{a}}$ & $6,20 \pm 1,09^{\mathrm{a}}$ & $6,00 \pm 1,11^{\mathrm{a}}$ & $5,85 \pm 1,18^{\mathrm{a}}$ \\
Color & $6,28 \pm 1,06^{\mathrm{a}}$ & $6,25 \pm 0,88^{\mathrm{a}}$ & $6,20 \pm 1,05^{\mathrm{a}}$ & $6,02 \pm 0,97^{\mathrm{a}}$ & $5,97 \pm 1,10^{\mathrm{a}}$ \\
Overall acceptance & $4,79 \pm 0,45^{\mathrm{a}}$ & $4,72 \pm 0,57^{\mathrm{a}}$ & $4,69 \pm 0,50^{\mathrm{a}}$ & $4,69 \pm 0,66^{\mathrm{a}}$ & $4,69 \pm 0,63^{\mathrm{a}}$ \\
Purchase intent & $4,68 \pm 0,58^{\mathrm{a}}$ & $4,62 \pm 0,60^{\mathrm{a}}$ & $4,47 \pm 0,89^{\mathrm{a}}$ & $4,52 \pm 0,85^{\mathrm{a}}$ & $4,31 \pm 0,92^{\mathrm{a}}$ \\
\hline
\end{tabular}

Source:Authors (2013).

Note: Different letters in the line indicate significant difference by Tukey's test $(p<0.05)$; SD:Standard deviation; FI: standard; F2: $20 \%$ of inulin; F3: $25 \%$ of inulin; F4: $30 \%$ of inulin; F5: $35 \%$ of inulin.

There was not meaningful difference ( $p>0.05)$ between the samples related to the attributes aroma, texture and color, corroborating with studies from Moscatto et al. (2004) who evaluated the chocolate cake acceptability added with inulin (6\%) among adults.

It is noteworthy that during the preparation of the bread formulations, the higher levels of inulin added to the mass resulted in softer mass, making it difficult for the mass modeling. However, as previously mentioned, this technological texture change was not detected by children after cooking.

Evaluating the attribute appearance, it is possible to verify that sample F5 was less accepted by the judges, showed a significant difference from the standard sample (F1) $(\mathrm{p}<0.05)$, but without a statistical difference among the other samples, containing inulin. Yet, research with adult judges (MOSCATTO et al, 2010), evaluating biscuits type cookies added 10, 20 and 30\% with inulin, resulted in lower appearance scores in products containing 30\% of ingredient.

Some researches confirm that the presence of inulin in products can modify their appearance. Peressini and Sensidoni (2009) verified that additions of 5 and $7.5 \%$ inulin increased the growth of bread dough, what was also verified in this survey. Yet, Wang, Wilson and Griffith (2002) found that the mass height was lower when added $3 \%$ inulin to the dough. According to Morris and Morris (2012), inulin can interfere to the elasticity and deformation resistance of masses, interfering in gluten network, resulting in a product with lower final development volume, effect observed in the present work. These technological changes may explain the lower scores for appearance to the sample with higher inulin content.

For the taste attribute, the standard formulation (F1) showed greater acceptance $(p<0.05)$ than F5, without statistical difference from the others, whose results were also verified by Aplevlicz and Dias (2010). This fact can be explained because inulin 
is slightly sweet, representing only $10 \%$ of the sweetness of sucrose (ISIK et al., 2011), which was reduced in the formulations of the present research.

Despite the lower evaluation for appearance and taste attributes of F5, issues of global acceptance and purchase intention received positive results, since the judges did not detect differences between the standard samples and those with inulin ( $p>0.05)$.

It is noteworthy that global products acceptability obtained a score within the recommended by the National Fund for Education Development (ENDF) (4-5 points in facial hedonic scale of 5 points). Therefore, this product could be inserted in

Figure 1 - Distribution of judges by hedonic values (1-7) obtained in the evaluation of the attributes appearance, aroma, taste, texture and color of flavored pineapple bread formulations standard and enriched with 20, 25, 30 and $35 \%$ inulin
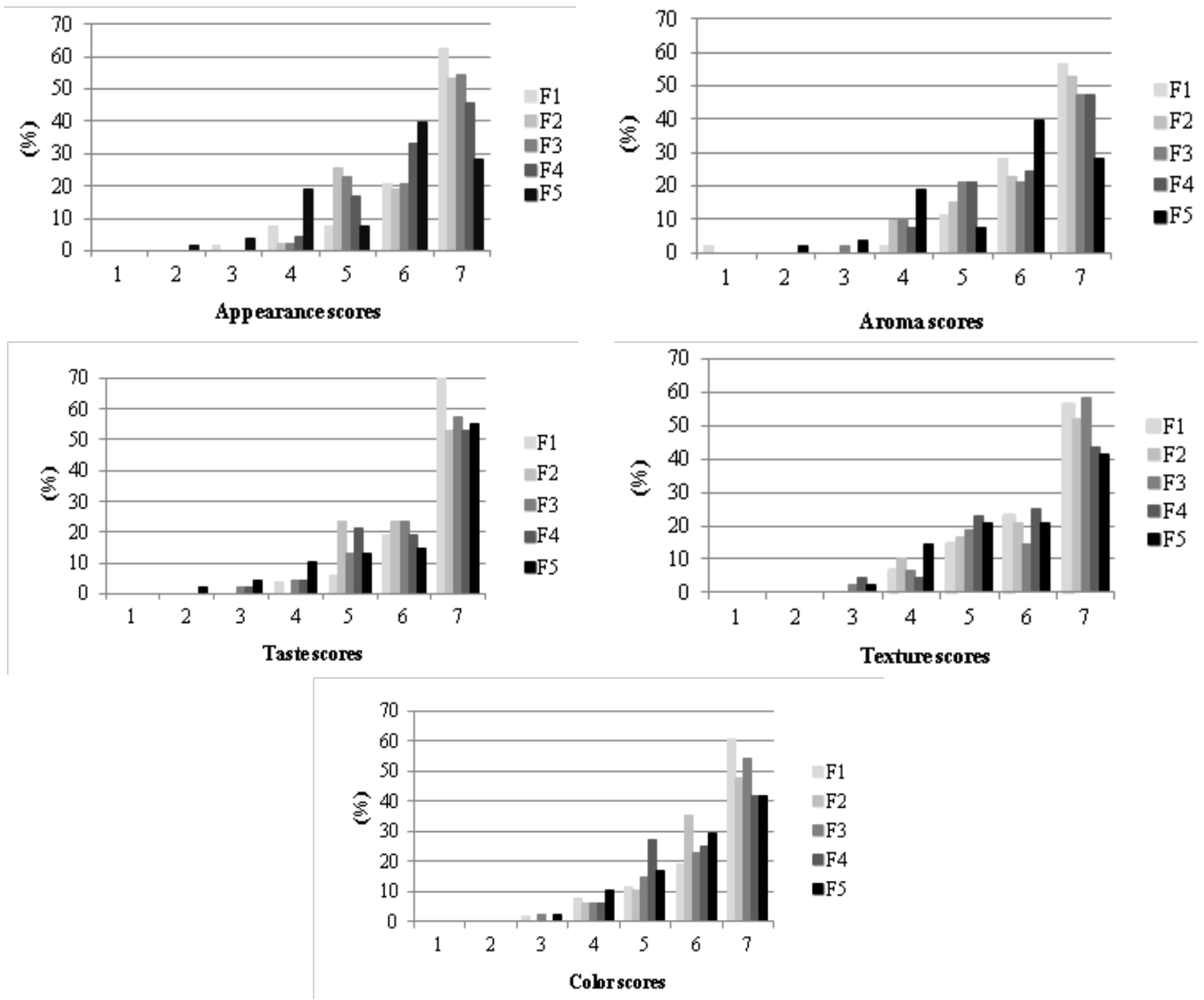

Source:Authors (2013). 
school snacks due to the high acceptance by children (above 4 points) (BRASIL, 2009).

In Figure 1 we can observe the judges distribution by hedonic values obtained in the evaluation of attributes of flavored bread standard and inulin added.

In general, scores 6 (very good) and 7 (super good) were the most frequently mentioned by the judges, showing that the inulin addition on bread was well accepted by children, generating results that were confirmed by assessing the acceptability index of formulations which is shown in Figure 2.

All samples showed IA above 70\% (Figure 2), which considers the products with good sensory acceptability, according to Teixeira et al. (1987).

According to Alamanou et al. (1996) attributes like aroma and taste are the most important characteristics which influence the sensory properties of food products added with different ingredients. As a result, the sample F4 (30\% inulin) was selected for comparison purposes, with the pattern (F1), for being the one with the highest content of inulin and similar acceptance to the standard (taste attribute).

\section{Physico-chemical analyzes}

In Chart 3 it is possible to verify the physico-chemical composition and Reference Daily Value (DV) of flavored pineapple standard bread and added with $30 \%$ inulin, compared to a reference product.

Higher moisture and protein contents were verified for the F1 $(p<0.05)$. Both formulations are in accordance with recommendation of the RDC №. 90, the National Health Surveillance Agency (ANVISA), which defines a maximum of $38 \%$ moisture to bread (BRASIL, 2000). The

Figure 2 - Acceptability index of formulations flavored pineapple bread standard and enriched with $20,25,30$ and $35 \%$ inulin, relative to the evaluated attributes

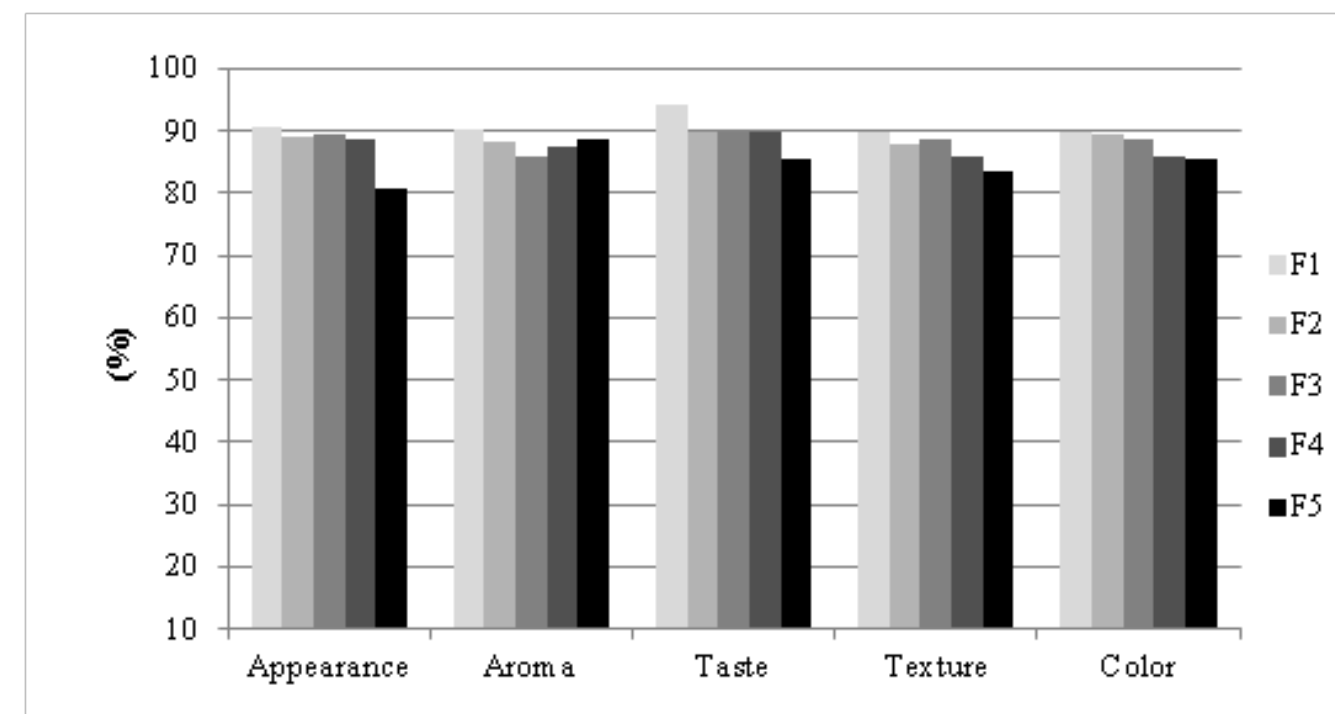

Source:Authors (2013). 
Chart 3 - Physico-chemical composition and Reference Daily Value - DV * (50 grams middle portion) of standard bread (F1) and added to $30 \%$ inulin (F4), compared with the reference product $* *$

\begin{tabular}{|c|c|c|c|c|c|}
\hline \multirow{2}{*}{ Evaluation } & \multicolumn{2}{|l|}{ F1 } & \multicolumn{2}{|c|}{ F4 } & \multirow{2}{*}{ Reference $^{* *}$} \\
\hline & Mean \pm SD & $\mathrm{DV}(\%)^{*}$ & Mean \pm SD & $\mathrm{DV}(\%)^{*}$ & \\
\hline Moisture (\%) & $33,24 \pm 0,00^{\mathrm{a}}$ & ND & $24,51 \pm 0,04^{b}$ & ND & 25,80 \\
\hline Ash $\left(\mathrm{g} \cdot 100 \mathrm{~g}^{-1}\right)^{* * * *}$ & $0,56 \pm 0,02^{\mathrm{a}}$ & ND & $0,50 \pm 0,01^{\mathrm{a}}$ & ND & 1,50 \\
\hline Proteins $\left(\mathrm{g} .100 \mathrm{~g}^{-1}\right)^{* * * *}$ & $8,02 \pm 0,02^{a}$ & 6,38 & $6,79 \pm 0,05^{b}$ & 5,40 & 8,40 \\
\hline Lipids $\left(\mathrm{g} .100 \mathrm{~g}^{-1}\right)^{* * * *}$ & $2,51 \pm 0,05^{a}$ & 1,90 & $2,58 \pm 0,09^{a}$ & 1,96 & 2,80 \\
\hline Carbohydrate (g.100 $\left.\mathrm{g}^{-1}\right)^{* * * *}$ & $55,66 \pm 0,07^{b}$ & 10,75 & $65,62 \pm 0,02^{\mathrm{a}}$ & 12,67 & 61,50 \\
\hline Calorie value (kcal.100g-1 $)^{* * * k}$ & $280,85 \pm 0,28^{a}$ & 7,64 & $239,27 \pm 0,46^{\mathrm{b}}$ & 6,64 & 311,00 \\
\hline Crude fiber (g.100g $\left.{ }^{-1}\right)^{* * *}$ & $7,12 \pm 0,03^{b}$ & ND & $9,03 \pm 0,10^{a}$ & ND & ND \\
\hline
\end{tabular}

Source:Authors (20/3).

Note: Different letters in the line indicate significant difference by student's test $(p<0.05)$; *DV: nutrients evaluated by the average of the DRI (2005), with base in a diet of I.802,55 kcal/day; ** Values compared with "Traditional homemade bread" (TACO, 20I I); *** Results expressed in humid base; SD: Standard deviation; ND: not available.

higher moisture content recorded on F1 can be explained according to Morris and Morris (2012), water absorption is reduced by inulin addition. Yet, the highest protein content in the sample pattern can be explained by the greater amount of flour present in this formulation, which has a higher protein content in their composition $(9.8 \%)(\mathrm{TACO}, 2011)$ than inulin (0\%) $\left(\mathrm{BENEO}^{\circledR} \mathrm{HP}, 2012\right)$. However, both $\mathrm{F} 1$ and $\mathrm{F} 4$ showed lower results than the reference product $($ TACO, 2011)

Despite the reduction in the protein content of the inulin product added(F4), which somewhat reduces its nutritional value, it was possible to lower the calorie content of $14.81 \%$, a beneficial fact for children, since a smaller calorie intake reduces the risk of chronic diseases in the future (SILVEIRA; ABREU, 2006).

There was no meaningful difference between the formulations in ash and lipids evaluations. Through Chart 3 we can see that higher levels of carbohydrates and crude fiber were observed in the formulation with inulin, increasing also the DV product. This fact is justified because inulin has high carbohydrate levels (96.87\%) and fiber (96.87\%) in their chemical composition (BENEO ${ }^{\circledR} \mathrm{HP}, 2012$ ), when compared to wheat flour $(75.1 \%$ and 2.3\%) (TACO, 2011).

It stands out as the main result of this work the fiber content found in the formulation F4 (9.03 g.100g-1), expressing a meaningful increase of $26.82 \%$ compared to F1. This is due mainly to the high content of dietary fiber showed in inulin. These results make the product into an excellent choice for school, considering the low fiber intake by this group (RINALDI et al.,2008). According to Brazilian legislation (BRASIL, 2012), it is considered as a good source of dietary fiber when the food presents at least $6 \%$ fiber.

\section{Conclusion}

The products development proved that an addition level up to $30 \%$ inulin in flavored bread was well accepted by the judges, obtaining sensory acceptance similar to standard product. The adding of $30 \%$ 
inulin provided the increase in nutrients such as carbohydrates and reduced proteins, humidity and calories. It is noteworthy that inulin addition to bread made a high fiber intake possible, improving the nutritional product profile. Thus, inulin can be considered a potential ingredient with functional properties that can be offered to schoolage children, showing good marketing expectations acceptance.

\section{References}

ALAMANOU, S. et al. Influence of protein isolate from lupin seed (Lupinus albus. ssp. Graecus) on processing and quality characteristics of frankfurters. Meat Science, Champaign, v.42, n.1, p.79-93, 1996.

AOAC International. Official Methods of Analysis of AOAC International. 18. ed. 4 rev. Gaithersburg: MD, USA, 2011.

APLEVLICZ, K. S.; DIAS, L. F. Suplementação de inulina em biscoitos tipo cookie. Food Ingredients Brasil, São Paulo, v.1, n.11, p.34-38, 2010.

$\mathrm{BENEO}^{\oplus}$ HP. Product Sheet Beneo ${ }^{\circledR}$ HP, Orafti, DOC.A4-05*01/02-B. Disponível em: $<$ http://www.orafti.com>. Acesso em: 25 abr. 2013.

BLIGH, E. G.; DYER, W. J. A rapid method of total lipid extraction and purification. Canadian journal of biochemistry and physiology, Ottawa, v.37, n.8, p.911-917, 1959.

ISIK, U.; BOYACIOGLU,D.; CAPANOGLU, E.; ERDIL,D. N. Frozen yogurt with added inulin and isomalt. Journal of Dairy Science, Champaign, v.94, n.4, p.1647-1656, 2011.

BRASIL. Ministério da Saúde. Agência Nacional de Vigilância Sanitária. Resolução RDC no -90 , de 18 de outubro de 2000. Aprova o regulamento técnico para fixação de identidade e qualidade de pão. Diário Oficial [da] República Federativa do Brasil, Brasília, DF, 2000.

BRASIL. Ministério da Educação. Fundo Nacional de Desenvolvimento da Educação. Resolução/FNDE/CD/n. 38, de 16 de Julho de 2009. PNAE. Brasília, DF, 2009.

BRASIL. Resolução RDC no 54, de 12 de novembro de 2012. Regulamento Técnico sobre Informação Nutricional Complementar. Diário Oficial [da] República Federativa do Brasil, Brasília, DF, 2012.

DIETARY REFERENCE INTAKES (DRI). Dietary Reference Intakes for energy, carbohydrate, fiber, fat, fatty acids, cholesterol, protein and amino acids. Washington, D.C.: The National Academies Press, 2005.

DUTCOSKY, S. D. Análise sensorial de alimentos. 3.ed. Curitiba: Champagnat, 2011.

FRANCK, A. Technological functionality of inulin and oligofrutose. British Journal of Nutrition, London, v.87, n.2, p.287-291, 2002. 
GRANATO, D.; MASSON, M. L.; RIBEIRO, J. C. B. Sensory acceptability and physical stability assessment of a prebiotic soy-based dessert developed with passion fruit juice. Ciência e Tecnologia de Alimentos, Campinas, v.32, n.1, p.119-125, 2012.

HERNÁNDEZ, T.; HERNÁNDEZ, A.; MARTINEZ, C. Concepto, propriedades y metodos de analisis. Revista Alimentaria, Madrid, v.4, n.261, p.19-30, 1995.

KIMMEL, S. A. A.; SIGMAN-GRANT, M.; GUINARD, J. Sensory testing with young children. Food Technology, Chicago, v.48, n.3, p.92-99, 1994.

MANTZOURIDOU, F.; SPANOU, A.; KIOSSEOGLOU, V. An inulin-based dressing emulsion as a potential probiotic food carrier. Food Research International, Serdang, v.46, n.1, p.260-269, 2012.

MERRILL, A. L.; WATT, B. K. Energy values of foods: basis and derivation. Agricultural Handbook, n.74, Washington, DC: USDA, 1973.

MEYER, D.; VERMULST, J.; TROMP, R. H.; DE HOOG, E. H. A. The effect of inulin on tribology and sensory profiles of skimmed milk. Journal of Texture Studies, Texas, v.25, n.1, p.1745-4603, 2011.

MEYER, P. D.; DE WOLF, J.; OLIVIER, P. Inulin und Fructooligosaccharide. In: ROSENPLENTER, K.; NÖHLE, U. (Ed.). Handbuch Süßungsmittel. Hamburg: Behr's Verlag, 2007. p. 155-189.

MINIM, V. P. R. Análise sensorial: estudo com consumidores. 2. ed. Viçosa: UFV, 2010.

MORRIS, C.; MORRIS, G. A. The effect of inulin and fructo-oligosaccharide supplementation on the textural, rheological and sensory properties of bread and their role in weight management: A review. Food Chemistry, Inglaterra, v.133, n.2, p.237-248, 2012.

MOSCATTO, J. A.; PRUDÊNCIO-FERREIRA, S. H.; HAULY, M. C. O. Farinha de yacon e inulina como ingredientes na formulação de bolo de chocolate. Ciência e Tecnologia de Alimentos, Campinas, v.24, n.4, p.634-640, 2004.

MUZZARELLI, R.A.A.; BOUDRANT,J.; MEYER, D.; MANNO, N.; DEMARCHIS, M.; PAOLETTI, M. G. Current views on fungal chitin/chitosan, human chitinases, food preservation, glucans, pectins and inulin: A tribute to Henri Braconnot, precursor of thecarbohydrate polymers science, on the chitin bicentennial: review. Carbohydrate Polymers, Barking, v.87, n.1, p.995-1012, 2012.

PERESSINI D.; SENSIDONI A. Effect of soluble dietary fibre addition on rheological and breadmaking properties of wheat doughs. Journal of Cereal Science, London, v.49, n.2, p.190-201, 2009.

RINALDI, A. E. M.; PEREIRA, A. F.; MACEDO, C. S.; MOTA, J. F.; BURINI, R. C. Contribuições das práticas alimentares e inatividade física para o excesso de peso infantil. Revista Paulista de Pediatria, São Paulo, v.26, n.3, p.271-277, 2008. 
SILVEIRA, S.; ABREU, S. M. Fatores que contribuem para a obesidade infantil. Revista de Enfermagem, Santo Amaro, v.7, n.1, p.59-62, 2006.

TABELA BRASILEIRA DE COMPOSIÇÃO DE ALIMENTOS (TACO). Núcleo de Estudos e Pesquisas em Alimentação. Universidade Estadual de Campinas [NEPA/Unicamp]. Tabela Brasileira de Composição de Alimentos. 4 ed. São Paulo: NEPA/Unicamp, 2011.

TEIXEIRA, E.; MEINERT, E.; BARBETTA, P. A. Análise sensorial dos alimentos. Florianópolis: UFSC, 1987.

VASCONCELOS,A.C.; PONTES,D.F.; GARRUTI,D. S.; SILVA, A.P.V.Processamento e aceitabilidade de pães de forma a partir de ingredientes funcionais: farinha de soja e fibra alimentar. Alimentação e Nutrição, Araraquara, v.17, n.1, p.43-49, 2006.

WANG, Z.; WILSON, G. F.; GRIFFITH, L. C. Calcium/Calmodulin-dependent Protein Kinase II Phosphorylates and Regulates the Drosophila Eag Potassium Channel. The Journal of Biological Chemistry, Rockville, v.277, n.27, p.24022-24029, 2002.

VON ATZINGEN, M. C. B. C.; PINTO E SILVA,M.E. M. Sensory characteristics of food as a determinant of food choices. Nutrire: Revista Sociedade Brasileira de alimentação e Nutrição, São Paulo, v.35, n.3, p.183-196, 2010. 